\title{
Continental-Margin SEISMiC STRATIGRAPHY: ASSESSING THE PRESERVATION POTENTIAL OF Heterogeneous Geological Processes OPERATING ON CONTINENTAL SHELVES AND SLOPES
}

By James A. Austin, Jr., Craig S. Fulthorpe, Gregory S. Mountain, Daniel L. Orange and Michael E. Field

\begin{abstract}
$\mathrm{T}$ HE STRATAFORM research program (Nittrouer and Kravitz, 1995) consists of three interrelated areas of multidisciplinary research (Nittrouer and Kravitz, 1996, this issue). The "stratigraphic sequences project" is attempting to understand creation of preserved stratigraphy along continental edges as the product of geological processes acting on a wide range of spatial and temporal scales. That goal is to be achieved by linking short-term (i.e., acting over hours to centuries) biological and physical processes (e.g., bioturbation, storms) to sequence stratigraphic architecture and facies, through remote sensing and coring. STRATAFORM's stratigraphic emphasis is on the upper $\sim 100 \mathrm{~m}$ of section and the last $\sim 10^{\circ}$ years of Earth's history.

The two "natural laboratories" chosen by STRATAFORM, the New Jersey and northern California margins, are characterized by different modern depositional regimes. The former study area is relatively quiescent; however, sequence stratigraphic geometries representing a variety of depositional inputs are well-developed for sediments within the space/time interval of STRATAFORM interest. Geometries and associated facies record the history of sea-level variation and continentalmargin progradation. An extensive seismic data-
\end{abstract}

J.A. Austin, Jr., C.S. Fulthorpe. Institute for Geophysics, The University of Texas at Austin. Austin. TX 78759. USA; G.S. Mountain, Lamont-Doherty Earth Observatory, Columbia University, Palisades, NY 10964, USA: D.L. Orange. Monterey Bay Aquarium Research Institute. Moss Landing. CA 95039, USA; M.E. Field. U.S. Geological Survey/MS999. Menlo Park, CA 94025, USA. base is available, and logged drill holes both onshore and offshore either exist or are planned. The latter study area is undergoing accretion; voluminous, fluvial sedimentation punctuated by floods and modulated by storms characterizes the margin. Depositional sequences are in places well-imaged; elsewhere, geological complexities, including acoustic masking by migrating gas and clathrates (frozen gas hydrates), obscure seismic profiles. Nonetheless, new knowledge of recent sedimentation off northern California should enable STRATAFORM's stratigraphy group to understand strata formation elsewhere, including the New Jersey margin. By studying the origins of such stratal geometries and related facies in different areas, STRATAFORM stratigraphers hope to use the preserved record to unravel recent terrestrial evolution, perhaps including rates of global climate change.

\section{Nested Scales of Seismic Images}

Seismic imaging and, by means of such geologic "pictures," mapping the surficial stratigraphy of the New Jersey and northern California margins require the collection of "nested" profiles. STRATAFORM focuses on processes determining stratal patterns at vertical scales of centimeters to 10 s of meters. Vertical resolution in reflection profiles is controlled by the acoustic source; unfortunately, no single source generates adequate energy across the wide range of frequencies needed to achieve such broad resolution. Consequently, STRATAFORM coordinates data acquisition so that coincident profiles are collected across depositional settings at a variety of temporal and spatial
... the New Jersey and northern California margins, are characterized by different modern depositional regimes... 


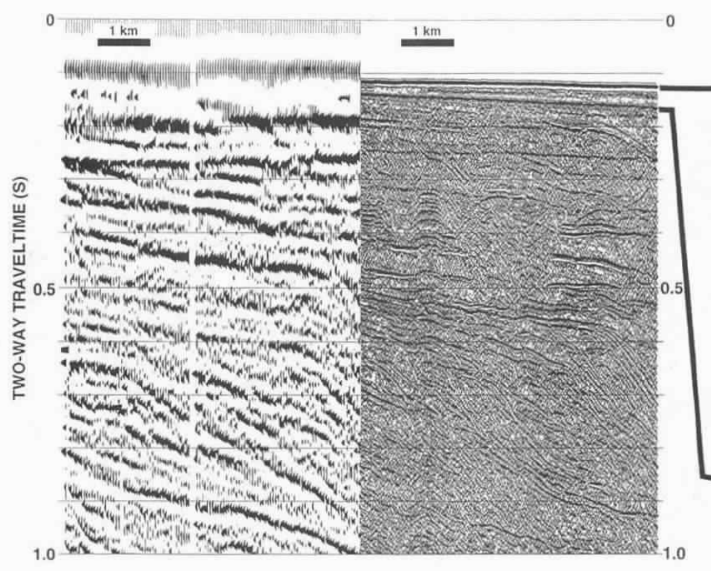

A

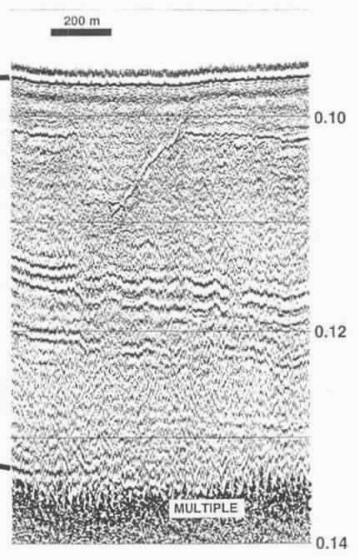

C

Fig. 1: The "nested" seismic approach, exemplified by three seismic profiles collected over the New Jersey outer shelf (for locations, refer to Fig. 2 inset). (A) 1970's oil industry multichannel seismic (MCS) data, filtered at 10-35 Hz (blue star, Fig. 2 inset). The top second represents $\sim 1 \mathrm{~km}$ of section; vertical resolution is probably $20 \mathrm{~m}(0.02 \mathrm{~s})$. Only vague, seawardprograding (i.e., dipping to the right) "clinoformal" reflections are visible at these frequencies, but such data provide critical regional coverage. (B) higher-resolution ( $5 \mathrm{~m}$ horizontally and vertically) MCS profile collected for STRATAFORM in 1995 (red star, Fig. 2 inset). The same traveltime window is displayed, but these "generator-injector" airgun data are filtered at 30-250 Hz. Note the increased "geological" detail. Prograding clinoform geometries $(<0.5 \mathrm{~s})$ are much better defined than in A. Channels (of late Pleistocene age, created by glacial meltwaters?) cut into the clinoforms; these channels ( 1-2 km across, 100-200 m deep) are not discerned on the industry data. (C) extremely high-resolution ( $\sim 5$ horizontally, $\sim 0.5 \mathrm{~m}$ vertically) Huntec single-channel profile, imaging the top $30 \mathrm{~ms}(\sim 25 \mathrm{~m})$ of section at 500-3,500 Hz (green star, Fig. 2 inset). These data reveal seawardprograding, "shingled" clinoforms, incised by very small ( 200 $\mathrm{m}$ across, $\sim 3 \mathrm{~m}$ deep) channels (see also Fig. 5) of latest Pleistocene age (>12,000 y but $<45,000$ y) (Austin et al., 1995). The deepest dipping reflections are also (just) visible on the high-resolution MCS profile $(\boldsymbol{B})$ collected nearby. Clearly, all three images are necessary in combination to understand the New Jersey margin's recent geological history.

coincident pro-

files are collected

across depositional

settings at a variety

of temporal and spa-

tial scales. lection of "high-resolution" (30-250 Hz) MCS data across the New Jersey margin in 1995 (Figs. 1 and 2); similar acquisition took place on the California margin in summer 1996. The sea floor on both margins, because it may be the best modern analogue for shallow subsurface horizons, is also being imaged in 3D for STRATAFORM (Goff et al., 1996, this issue).

\section{The Margin at Low Frequency: Systematic} Progradation Over the Past 20 Million Years

Existing oil industry data (Fig. 2) provide the only dense images of large areas necessary to understand the 3D processes responsible for depositional sequences and observed shelf/slope morphology. Spatial variations in sequence architecture are responses to change in one or more of the following: drainage basin area/relief and sediment supply, large-scale drainage patterns, subsidence, compaction, isostasy, and gravity-/current-driven sediment transport. Temporal variations in sequence geometries have a secular component resulting from changes in spatial controls, as well as a cyclic component caused by global sea-level change (eustasy).

On the New Jersey margin, pronounced shelf progradation occurred over the past $\sim 20$ million years, either in response to point sources of sediment or to distributed cross-shelf sediment transport (Greenlee et al., 1992). Plan views of buried "clinoform" breaks-in-slope are gently arcuate (Fig. 3), which suggests the following: 1) shelf progradation was directly related to major fluvial sediment inputs, e.g., the ancestral Hudson and Delaware rivers (Fulthorpe and Austin, 1995), but those inputs were more voluminous than they are today, and 2) lateral sediment dispersal away from point sources by along-shelf currents was highly efficient, muting the influence of such sources (C.S. Fulthorpe and J.A. Austin, unpublished observations). MCS data on the northern California margin also suggest that rivers dominated sequence development (Fig. 4). Because there is as yet little evidence for sediment transport across the shelf to clinoform breakpoints during lowstands, and because they lack the prominent submarine canyons prevalent on the modern slope (Fig. 2) (Pratson and Haxby, 1996), New Jersey clinoform fronts do not appear to be analogous to the modern shelf edge (C.S. Fulthorpe and J.A. Austin, unpublished observations). Furthermore, their distances from corresponding paleo-shorelines and precise relationships to sea-level history remain unknown; answering such questions is part of the overall goal of STRATAFORM, and an important reason for focusing on the New Jersey margin.

\section{The Margin at High Frequency: Stratigraphic} Complexity Unrelated to the Modern Seafloor

Ultra-high resolution, single-channel Huntec profiling in $3 \mathrm{D}$ has revealed seismic stratigraphic 
geometries in the upper $\sim 25 \mathrm{~m}$ of the New Jersey geological section that are unrelated to the modern seafloor (Davies et al., 1992; Austin et al., 1995). Small, buried (meltwater?) channels carved within the last 45,000 years (calibrated by ${ }^{14} \mathrm{C}$ dating) meander toward the modern shelf edge (Fig. 5). Such small features can be resolved only by interpreting profiles sampled at $0.1 \mathrm{~ms}$ and collected at a nominal $10 \mathrm{~m}$ spacing, at or near the limits of present seismic acquisition technology (Pulliam et al., 1996). Analyses of lithofacies, physical properties and foraminiferal biofacies of sediments recovered in piston and vibra-cores ( $<1$ to $>6 \mathrm{~m}$ long), spatially tied to these $3 \mathrm{D}$ seismic data, indicate that channels beneath the mid-shelf are filled with $\sim 12,000$-y-old mud deposited in a marginal marine environment; in contrast, similar-looking channels occurring within an outer-shelf sediment wedge are filled with sand $\sim 13,000-13,500$ y old (Davies et al., 1992). Intricate changes in depositional patterns associated with the last (Holocene) marine transgression across this shelf must be responsible for the observed stratigraphic differences; analysis of these results continues.

On the northern California margin, 2D Huntec images reveal different Quaternary sequence successions in the upper $20 \mathrm{~m}$ of the shelf versus slope sections (Fig. 6). Observed sequence stratigraphy beneath the shelf appears to be associated with recent coastal transgression over a well-defined unconformity, probably itself formed through multiple erosional events (Syvitski et al., 1996, this issue). Slope sequences suggest that stratigraphy is built largely by mass sedimenttransport processes. The outer shelf and upper slope are characterized by outcrops of hard sediments (Fig. 6), which may affect surface reflectivity patterns (Goff et al., 1996, this issue). Gas is important in this margin's stratigraphic evolution; gas is also a primary hindrance in seismically observing its stratigraphic succession. Seafloor pock marks and vertical washouts indicative of shallow gas are recognized in Huntec profiles. Pervasive gas is also believed to cause pronounced lateral amplitude variations (so-called "bright spots") observed in the Huntec data (Fig. 6). Such acoustic interference emphasizes the importance of STRATAFORM's "nested" seismic approach; gas does not mask seismic images equally at all frequencies.

\section{The Future: Mid-Frequency, "High-Resolution" Images and Comprehensive Sampling}

To complete the frequency/resolution spectrum in existing data, STRATAFORM investigators carried out a high-resolution $(30-250 \mathrm{~Hz})$, commercial MCS survey of the New Jersey margin in 1995 using differential Global Positioning System for precise navigation. Approximately $1,760 \mathrm{~km}$ of regional profiles were collected; these data image features like buried channels that were un-

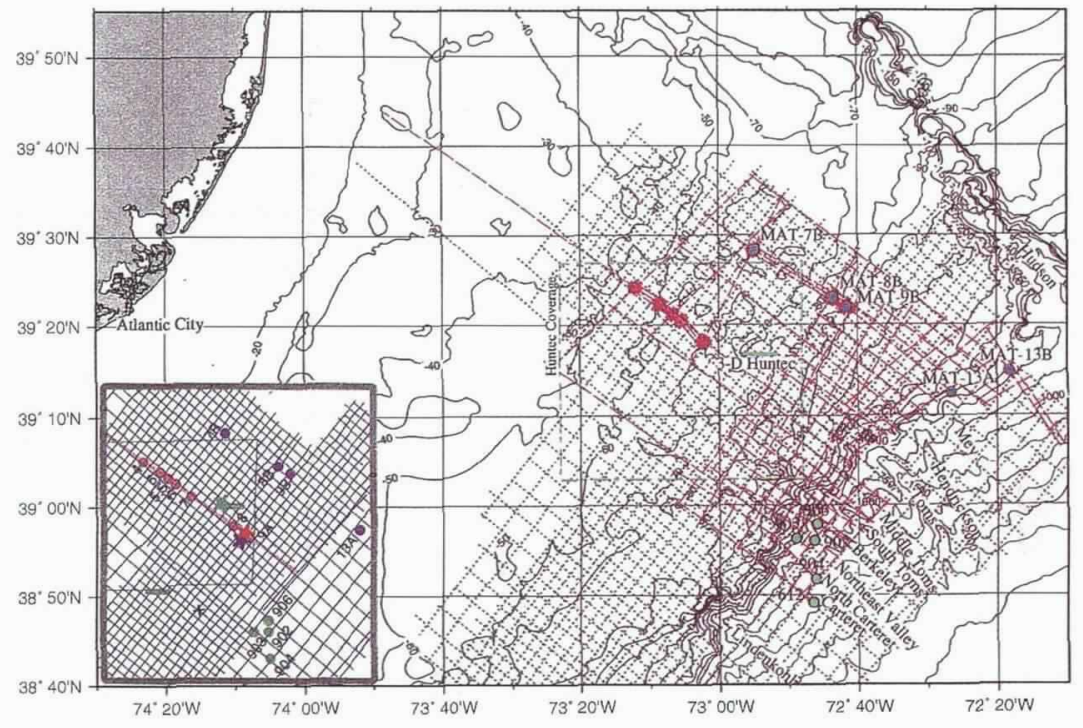

Fig. 2: "Nested" seismic coverage available on the relatively quiescent New Jersey margin, superimposed on bathymetry (depths in $m$ ). The shelf is wide; the slope is characterized by well-defined canyons. Oil industry MCS (blue dotted lines), high-resolution STRATAFORM MCS (red dashed lines), and two-dimensional and three-dimensional Huntec profiles (green dashed line box/solid rectangles, respectively) are shown. Inset shows locations (by stars of appropriate color) of Fig. 1 profiles. Leg 150 Ocean Drilling Program (ODP) sites on the slope (Mountain et al., 1994), along with Deep Sea Drilling Project (DSDP) Site 612 (Leg 95; Poag et al., 1987), are indicated (green dots). Mid-Atlantic Transect (MAT) sites are also shown (red dots); several of those (blue dots) will be drilled in summer 1997, the first time that $O D P$ will attempt to sample shelf sediments.

recognized in the lower frequency, oil-industry MCS data (Fig. 1B). A total of eight sites were also surveyed, at $150 / 300 \mathrm{~m}$ profile spacing, to assess the potential of encountering hydrocarbons while drilling on the New Jersey shelf (Fig. 2). These sites comprise a critical portion of the MidAtlantic Transect [MAT, drilled in part as Ocean Drilling Program (ODP) Leg 150/150x] (Mountain et al., 1994), designed to understand how the last $\sim 10^{7}$ million years of sea-level history has affected this margin's stratigraphic development. Three MAT shelf sites (7B, 8B, 9B; Fig. 2) will be drilled and logged by ODP during summer 1997; four additional sites (13A-D) are proposed for drilling on the slope. Drilling should provide the ultimate ground truth for the nested geophysical profiles and shorter sediment samples already collected for STRATAFORM.

A second high-resolution MCS effort was conducted on the northern California margin during summer 1996. When those data have been analyzed, the shallow stratigraphic architectures of both New Jersey and northern California margins should be known in comparable detail. The final challenge will be sampling ( $>10 \mathrm{~m}$ ) off California, to complement such activities off the east coast. Eventually, enough observational detail should be
The final challenge

will be sampling

(>10 m) off Califor-

nia, to complement

such activities off the

east coast. 


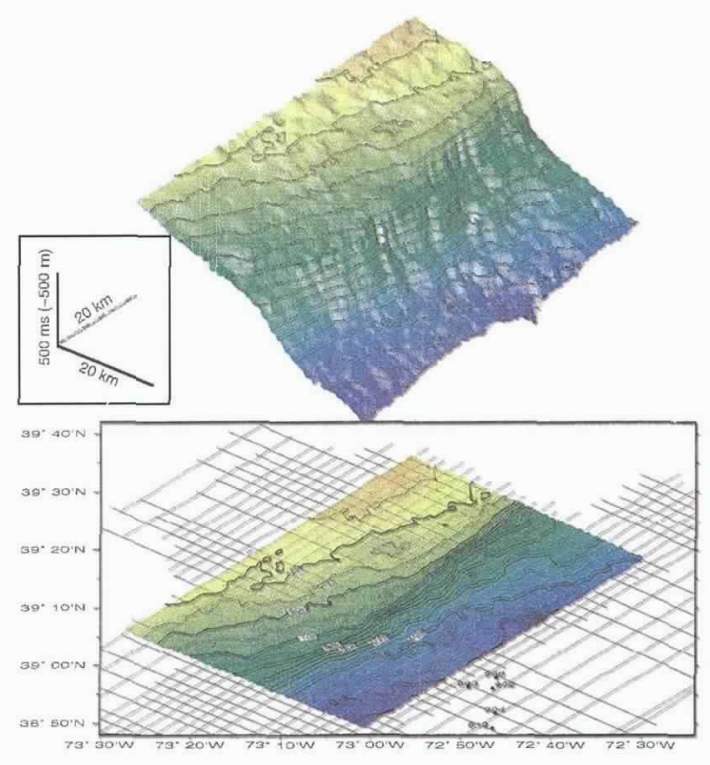

Fig. 3: Buried middle Miocene ( 12.5 million years; after Mountain et al., 1994) "clinoform" on the New Jersey margin. Bottom: two-way traveltime structure contours (in ms below sea level) superimposed on seismic control (i.e., oil-industry MCS grid, Fig. 2). ODP Leg 150 sites 902-904/906 and DSDP Site 612 are also shown (Fig. 2). Top: $3 D$ perspective shaded image (azimuth of artificial illumination $=220^{\circ}$ ), with traveltime contours superimposed. Both are viewed from the south, at an elevation of $30^{\circ}$ above the horizontal. This paleomargin's convex-seaward trend is a response to local patterns of sediment supply and erosion. Mapping of Miocene clinoforms confirms that the point of maximum progradation migrated southwest along the margin from $\sim 13.5$ to 8 million years (Greenlee and Moore, 1988; C.S. Fulthorpe and J.A. Austin, unpublished observations). In contrast, the modern shelf shows maximum progradation to the northeast, in the vicinity of Hudson Canyon (Fig. 2). The sparseness of Miocene canyons on the clinoform front contrasts markedly with the heavily dissected modern slope (Fig. 2), suggesting that rapid Miocene progradation involving massive sediment input inhibited canyon formation.

available for modeling to differentiate among the myriad depositional processes recorded by sequence stratigraphic successions from both study areas. That is an ultimate goal of STRATAFORM.

\section{Acknowledgements}

STRATAFORM is supported by the Office of Naval Research (Code 322GG, J. Kravitz, Program Manager). ODP's U.S. Science Support Program, administered by the U.S. Scientific Advisory Committee (USSAC) of JOI, Inc., also provided funds for New Jersey investigations. J. Yun, University of California/Santa Cruz, produced Figure
4, and J. Gardner, USGS/Menlo Park, provided Figure 6. The data shown in Figure 4 were collected by JEBCO Geophysical, courtesy of Amoco Corporation. The authors are grateful to the crews of the ships responsible for data collection, and to the capable support staff and students who make these kinds of complex data syntheses possible. UTIG Contribution Number 1233.

\section{References}

Austin, J.A., Jr., C.S. Fulthorpe, T.A. Davies and M.B. Lagoe, 1995: Unraveling the stratigraphic complexities of the last deglaciation: ultra-high resolution 3D seismic images of the New Jersey continental shelf [abs.]. EOS, $76,46,308$

Davies, T.A., J.A. Austin, Jr., M.B. Lagoe and J.D. Milliman, 1992: Late Quaternary sedimentation off New Jersey: new results from 3-D seismic profiles and cores. Mar. Geol., 108, 323-344.

Fulthorpe, C.S. and J.A. Austin, Jr., 1995: Sequence stratigraphic geometries and Neogene evolution of the New Jersey continental margin [abs.]. EOS, 76, 46, 308.

Goff, J.A., L.A. Mayer, J. Hughes-Clark and L.F. Pratson, 1996: Swath mapping on the continental shelf and slope: the Eel River Basin, northern California. Oceanography, 9, 178-182.

Greenlee, S.M., W.J. Devlin, K.G. Miller, G.S. Mountain and P.B. Flemings, 1992: Integrated sequence stratigraphy of Neogene deposits, New Jersey continental shelf and slope: comparison with the Exxon model. Geol. Soc. America Bull., 104, 1403-1411.

and T.C. Moore, 1988: Recognition and interpretation of depositional sequences and calculation of sea-level changes from stratigraphic data-offshore New Jersey and Alabama Tertiary. In: Sea-Level Changes: An Integrated Approach. C.K. Wilgus, B.S. Hastings, C.G. St. C. Kendall, H.W. Posamentier, C.A. Ross and J.C. Van Wagoner, eds. SEPM Spec. Pub. 42, 329-353.

Mountain, G.S., K.G. Miller, P. Blum, P.-G. Alm, M.-P. Aubry, L.H. Burckle, B.A. Christensen, J. Compton, J.E. Damuth, J.-F. Deconinck, L. de Verteuil, C.S. Fulthorpe, S. Gartner, G. Guèrin, S.P. Hesselbo, B. Hoppie, M.E. Katz, N. Kotake, J.M. Lorenzo, S. McCracken, C.M. McHugh, W.C. Quayle, Y. Saito, S.W. Snyder, W.G. ten Kate, M. Urbat, M.C. Van Fossen and A. Vecsei, 1994: Proc. ODP, Init. Repts., 150, College Station, TX (Ocean Drilling Program), 885 pp.

Nittrouer, C.A. and J.H. Kravitz, 1995: Integrated continental margin research to benefit ocean and earth sciences. EOS, 76, 121-126.

and J.H. Kravitz, 1996: STRATAFORM: a program to study the creation and interpretation of sedimentary strata on continental margins. Oceanography, 9, 146-152.

Poag, C.W., A.B. Watts, M. Cousin, D. Goldberg, M.B. Hart, K.G. Miller, G.S. Mountain, Y. Nakamura, A. Palmer, P.A. Schiffelbein, B.C. Schreiber, M. Tarafa, J.E. Thein, P.C. Valentine and R.H. Wilkens, 1987: Init. Repts., DSDP, 95, Washington, U.S. Government Printing Office, $817 \mathrm{pp}$.

Pratson, L.F. and W.F. Haxby, 1996: What is the slope of the U.S. continental slope? Geology, 24, 3-6.

Pulliam, J., J.A. Austin, Jr., E.C. Luhurbudi, S. Saustrup and P.L. Stoffa, 1996: An ultrahigh resolution 3-D survey of the shallow subsurface on the continental shelf of New Jersey. The Leading Edge, 15, 839-845.

Syvitski, J.P., C.R. Alexander, M.E. Field, J.V. Gardner, D.L. Orange and J.W. Yun, 1996: Continental-slope sedimentation: the view from northern California. Oceanography, 9, 163-167. 


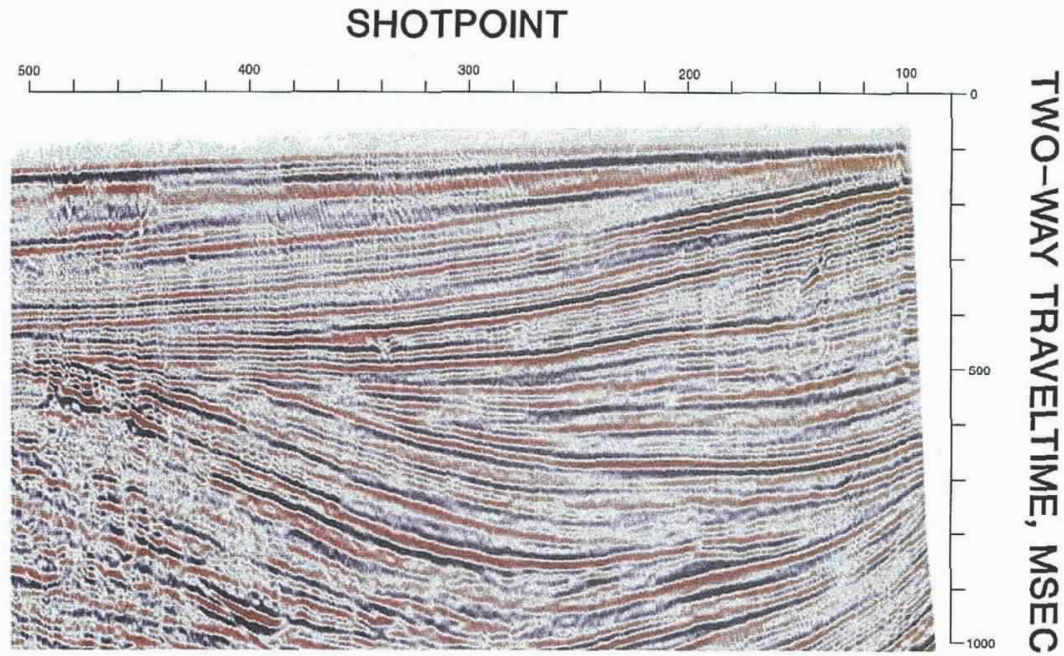

Fig. 4: Portion of a low-frequency $(16-40 \mathrm{~Hz})$, oil industry MCS line crossing part of the Eel River basin on the northern California continental shelf (Goff et al., 1996, this issue). Vertical axis is in traveltime (milliseconds); the amount of section shown is $\sim 1 \mathrm{~km}$. Horizontal axis is in shotpoints (1 shotpoint $=30 \mathrm{~m}$ ); resultant vertical exaggeration of this image is $\sim 5-7 \times$. Seafloor deepens to the left (westward). Reflectors resemble wedges; such geometries suggest either episodic deposition from a single (fluvial) source or interfingering delta lobes from both the Eel and Mad rivers (Goff et al,, 1996, this issue). Below $700 \mathrm{~ms}$ to the west, the chaotic acoustic pattern observed may be caused by migrating gas, large sedimentary structures, and/or basement deformation.

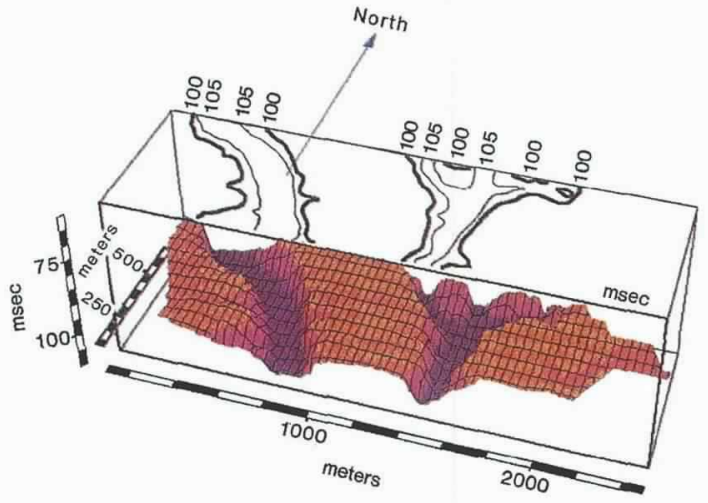

Fig. 5: Perspective view (from the south-southeast) of the western third of a Huntec three-dimensional grid on the New Jersey shelf (Fig. 2) showing a meandering system of shallowly buried (by $\sim 5 \mathrm{~m}$ of section) channels (see also Fig. 1C). Drainage is presumably to the south/south-southeast, toward the modern shelf edge. Horizontal scales are in $m$, vertical scale in traveltime ( $m s$, one division $=\sim 3.75 \mathrm{~m}$ ) from the sea surface (water depths $\sim 90 \mathrm{~ms} / 70 \mathrm{~m}$ ). Individual channels are up to $10 \mathrm{~ms}(\sim 7.5 \mathrm{~m})$ deep and $\sim 200 \mathrm{~m}$ wide. Superimposed on the perspective view is a structure map (in ms below sea surface, contour interval $\sim 3.75 \mathrm{~m}$ ) of the same horizon.

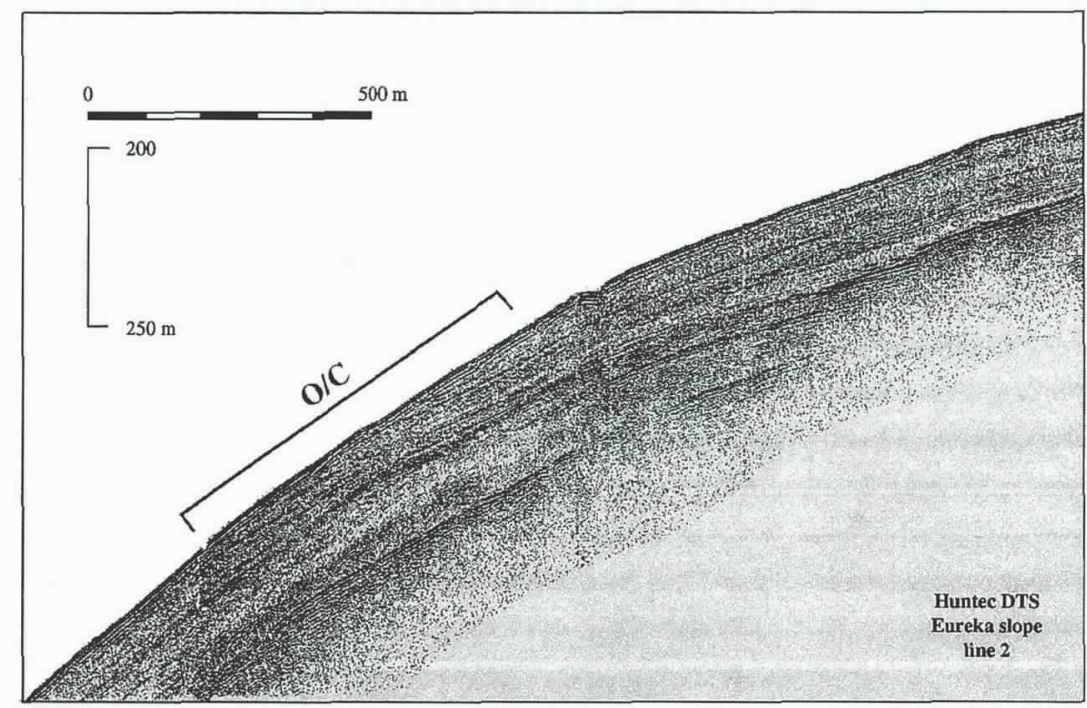

Fig. 6: Huntec two-dimensional profile in water depths of $\sim 200-300 \mathrm{~m}$ on the northern California slope, showing acoustically well-stratified sediment. Very bright (high-amplitude) reflections may be caused by gas-charged sediments. An outcrop $(\mathrm{O} / \mathrm{C})$ of subsurface layers is present, a common occurrence along this part of the upper slope. These outcrops may be the result of erosion by intensified bottom currents caused by shoaling internal waves ( $D$. Cacchione, personal communication, 1995). This possibility will be tested using moored instruments in the next phase of STRATAFORM (Syvitski et al., 1996, this issue). 